\title{
La traducción de los referentes culturales e intertextuales en el subtitulado: el caso de FRIENDS $^{1}$
}

\section{(The translation of cultural and intertextual referents in subtitling: the case of FRIENDS)}

ELENA R. MURPHY

(Universidad de Salamanca)

Fecha de recepción: 25 de febrero de 2010

Fecha de aceptación: 30 de abril de 2010

Resumen: El interés que suscita el estudio de los textos audiovisuales traducidos y su proceso de traducción ha crecido exponencialmente a lo largo de los últimos años. De entre las múltiples líneas de investigación dentro del ámbito de la traducción audiovisual, en este artículo se analiza la manera en que se traducen los referentes culturales e intertextuales a través de una de las modalidades de la TAV, el subtitulado, teniendo en cuenta los significativos avances producidos en los estudios de traducción a lo largo de los últimos años. Se ofrece un estudio de las soluciones adoptadas por el "subtitulador" ante la traducción de las referencias culturales e intertextuales presentes en los diálogos de la famosa serie Friends, tomando en consideración los aspectos que influyen en la decisión final y la creciente interconexión entre los diferentes lenguajes y culturas de las sociedades de la globalización.

Palabras clave: traducción audiovisual, subtitulado, referentes culturales e intertextuales, interconexión, globalización.

\begin{abstract}
Interest in the study of audiovisual translation and its production process has rapidly been gaining ground during the last few years. Within the different lines of research in this area, this paper focuses on the ways in which cultural and intertextual elements are rendered through one of the many forms of audiovisual translation: subtitling. A detailed analysis of the decisions made by the "subtitler" in regard to the different cultural and intertextual elements present in the dialogs of the famous TV series Friends is offered, taking into consideration the significant developments that have occurred within the field of Translation Studies as a whole and the ever-growing
\end{abstract}

\footnotetext{
${ }^{1}$ Este artículo se incluye dentro del proyecto "Traducción y discursos políticos: conflictos éticos e ideológicos en la era de la inmigración y la globalización”, FFI2009-10697, financiado por el Ministerio de Ciencia y Tecnología.
} 
interconnexion between languages and cultures in the globalised societies of our time.

Key words: audiovisual translation, subtitling, cultural and intertextual elements, interconnexion, globalization.

1. ENTRE CULTURAS: LA TRADUCCIÓN AUDIOVISUAL TRAS EL GIRO CULTURAL

Las transformaciones acaecidas en los estudios de traducción durante los últimos años han sido espectaculares. Desde una visión prescriptivista y cientifista en la que el traductor era una figura secundaria, un mero puente entre autor original y lector, la visión contemporánea de la traducción entiende que ésta es un proceso muy complejo que va mucho más allá de la tradicional equivalencia absoluta. Autores como Susan Bassnett (1980), Theo Hermans (1985), Mary Snell-Hornby (1988) o André Lefevere (1992) dieron un vuelco a nuestra disciplina con la incorporación de conceptos como los de reescritura, ideología, poder o mecenazgo, que fueron fundamentales para el posterior desarrollo de la disciplina. Hemos pasado de centrar nuestros esfuerzos en consideraciones lingüísticas y textuales a entender la cultura como unidad principal de traducción. Es decir, dejamos atrás los análisis normativos y prescriptivos para dar lugar a los acercamientos descriptivos.

Desde los años ochenta, los estudios de traducción se han diversificado y se han enriquecido considerablemente de nuevos enfoques. Uno los ámbitos de estudio que ha proliferado en los últimos años dentro de la disciplina traductológica ha sido el de la traducción audiovisual ${ }^{2}$. Como señalan Zabalbeascoa, Santamaría y Chaume (2005: IX),

Esta actividad profesional merecía más atención [...] El número de consumidores de estos productos, que se incrementa cada día en todo el mundo, el volumen económico que tal actividad representa, la popularidad de los medios audiovisuales, el deseo de tantos estudiantes de dedicarse a los medios de comunicación, el uso de los medios por parte de los diferentes poderes y estamentos sociales, obligaba a los círculos universitarios a prestar la atención que merecen los textos audiovisuales traducidos y su proceso de traducción.

\footnotetext{
${ }^{2}$ Es preciso señalar que, como indica Diaz Cintas (2001:23), debido a la gran cantidad de condicionamientos técnicos que influyen en la transmisión lingüística dentro del ámbito audiovisual, algunos teóricos prefieren catalogar este tipo de trasferencias como ejemplos de adaptación más que de traducción.
} 
La traducción audiovisual no tenía cabida en el ámbito traductológico de los años sesenta. Esto se puede observar en enfoques como el de Jackobson que, en su frecuentemente citado artículo "On Linguistic Aspects of Translation" (1959), establece tres tipos de traducción: intralingüística o rewording (la interpretación de signos verbales por medio de otros signos de la misma lengua); interlingüística o proper translation (la interpretación de signos verbales por medio de signos de otras lenguas); e intersemiótica o transmutation (la interpretación de signos verbales por medio de signos de sistemas no verbales). Sin embargo, esta situación ha cambiado, "[t]ranslation carried out in the audiovisual field currently accounts for an increasingly large proportion of translation activity" (Díaz Cintas 2003: 193). Teniendo en cuenta este crecimiento y la enorme cantidad de productos audiovisual que se importan para Europa, y en especial para España, no resulta complicado entender el importante aumento de la investigación dentro de este campo epistemológico. De entre las múltiples líneas de investigación dentro del ámbito de la traducción audiovisual, en este artículo pretendemos analizar la manera en que se traducen los referentes culturales e intertextuales ${ }^{3}$ a través de una de las modalidades de la TAV, el subtitulado, teniendo en cuenta los significativos avances producidos en los estudios de traducción a lo largo de los últimos años.

Hoy en día, la actividad traductora ya no se considera circunscrita exclusivamente a la producción literaria. Tras el giro cultural, la rama descriptiva de los estudios de traducción evidenció un cambio significativo. Frente a los primeros acercamientos descriptivistas, más enfocados hacia temas literarios, comenzaron a proliferar las publicaciones que ponían de relieve cuestiones de ideología y poder relacionadas con la práctica traductora en las que se vislumbraban fundamentos postestructuralistas. Diferentes autores se centraron en la figura del traductor como agente manipulador y resaltaron la trascendencia de la práctica traductora en diversos ámbitos disciplinares. A partir de los años ochenta, cobraron gran importancia los aspectos ideológicos y políticos dentro del campo de la traducción. Esta actividad se empieza a entender como punto de encuentro entre diferentes discursos, un espacio en el que se negocian las relaciones de poder en un momento y un lugar determinados:

translation is not a by-product, nor simply a consequence, of social and political developments, nor is it a by-product of the physical movement of texts and people. It is part and parcel of the very process that makes

\footnotetext{
${ }^{3}$ Según Rosa Agost (1999: 103), se puede entender la intertextualidad como "la aparición, en un texto, de referencias a otros textos".
} 
these developments and movements possible in the first place (Baker 2006: 6).

Por tanto, el traductor no se considera como un intermediario neutro, sino que participa activamente en el proceso translatorio. En este sentido, retomamos aquellas ideas de manipulación y reescritura, que André Lefevere introdujo en su artículo "Why Waste Our Time on Rewrites?" en 1985 y que, posteriormente, desarrolló en 1992 en su obra Translation, Rewriting and the Manipulation of Literary Fame. En dicho libro, Lefevere establece que toda reescritura implica inevitablemente manipulación. Según Lefevere, de entre las distintas posibilidades, la traducción es "the most obviously recognizable type of rewriting" (Lefevere 1992: 9). Las reescrituras - traducciones se producen siempre en función de una determinada ideología "the world view-of a certain society at a certain moment" (Lefevere 1985: 226), que puede ser propia del traductor/reescritor o, por el contrario, serle impuesta por el mecenazgo "the powers (persons, institutions) which help or hinder the writing, reading and rewriting of literature" (ibid: 227). Además, en el sistema literario también influyen otras restricciones (constraints) como la poética del momento "what literature should (be allowed to) be" (ibid: 226) y el universo del discurso "the knowledge, the learning, but also the objects and the customs of a certain time, to which writers are free to allude in their work" (ibid: 232-233). Según Lefevere, el mecenazgo, más preocupado por la ideología de la literatura que por la poética, está formado por tres elementos: el componente ideológico, el componente económico y el estatus. Sin duda, la ideología impuesta por el o los mecenas ordena las acciones y decisiones del reescritor. Asimismo, el factor económico tiene gran importancia en la realización de la reescritura y en el resultado final, "[e]s la influencia del oro en la letra" (Moya 2004: 156).

Los conceptos de ideología, mecenazgo, constraints o restricciones y universo del discurso, definidos anteriormente en el ámbito de la traducción literaria, me parecen extrapolables a la traducción audiovisual. Como cualquier traductor, ya sea literario, audiovisual, científico o jurídico, el subtitulador no traduce desde la neutralidad, sino entre culturas, con una ideología específica y en un momento determinado. Además, responde a un mecenas y debe atenerse a unas restricciones ${ }^{4}$ (o constraints) de espacio, sincronía, velocidad de lectura... De esta manera, el texto final será el resultado de una serie de decisiones traductológicas, guiadas por diferentes restricciones y consideraciones culturales.

\footnotetext{
${ }^{4}$ En este sentido, Titford (1982) se ha referido a la labor de subtitulación como traducción subordinada o constrained translation, teniendo en cuenta las restricciones impuestas por el medio a la hora de subtitular.
} 
En las páginas siguientes trataremos de analizar las soluciones ofrecidas por el subtitulador a la traducción de las referencias culturales e intertextuales, teniendo en cuenta los aspectos que influyen en la decisión final y la creciente interconexión entre los diferentes lenguajes y culturas de las sociedades de la globalización. Para ello, nos centramos en los dos primeros episodios de la serie estadounidense Friends, que se ha importado a España doblada, como otras muchas, pero de la que existen versiones en VO subtituladas.

Partimos de la base de que, en la actualidad, la mayor parte de las culturas ya no resultan entes cerrados, sino organismos abiertos e interrelacionados entre sí. Hoy más que nunca, el traductor se ha convertido en un mediador intercultural $y$, por ello, debe conocer tanto las lenguas como las culturas entre las que traduce. En este contexto, cobran gran importancia los referentes culturales que, en palabras de Agost (1999: 99), se pueden definir como "todos los elementos que hacen que una sociedad se diferencie de otra, que cada cultura tenga su idiosincrasia". Según esta misma autora,

Los elementos culturales que presentan problemas a la hora de traducir suelen ser: lugares específicos de alguna ciudad o de algún país; aspectos relacionados con la historia, con el arte y con las costumbres de una sociedad y de una época determinada (canciones, literatura, conceptos estéticos); personajes muy conocidos, la mitología; la gastronomía, las instituciones, las unidades monetarias, de peso y medida; etc. (id)

Ante la especificidad de estos elementos, el subtitulador/traductor podrá seguir diferentes estrategias dependiendo de diversos factores como la mayor o menor cercanía entre los grupos culturales, el encargo al que responde o las características de los receptores potenciales. Jan Pedersen (2005) ha clasificado dichas estrategias según su grado de extranjerización o domesticación, atendiendo a las ideas de Venuti ${ }^{5}$ :

\footnotetext{
${ }^{5}$ Este autor retoma aquélla doble vía de actuación propuesta por Schleiermacher y considera que, ante un texto, el traductor tiene dos posibilidades: optar por favorecer la aceptabilidad del mismo en el contexto receptor o su adecuación a la cultura de origen. Venuti añade ciertos matices a las ideas de Schleiermacher con el fin de describir la situación traductora en el ámbito anglosajón. De esta manera, establece dos nuevos conceptos, extranjerización y domesticación, que han adquirido gran relevancia en el campo traductológico occidental a lo largo de los últimos años.
} 


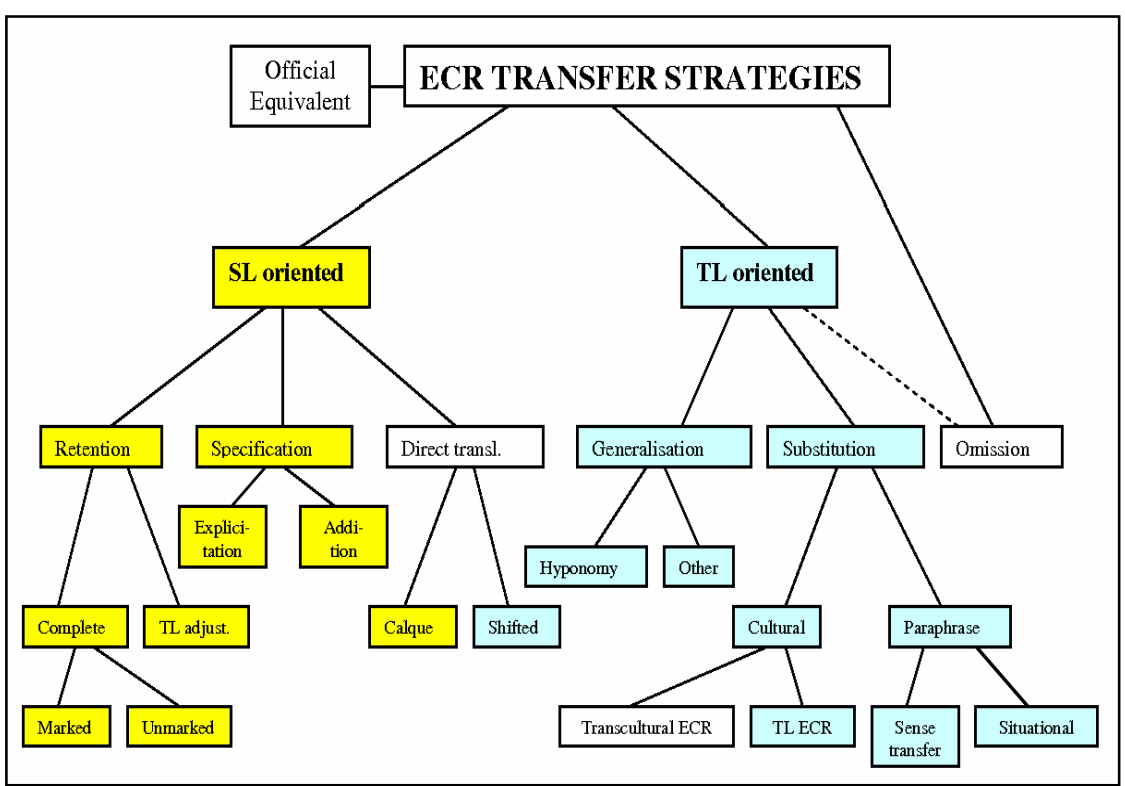

Esquema de Pedersen (2005: 116)

Por su parte, Agost (1999:100-101) plantea cuatro estrategias que se pueden adoptar ante la traducción de los referentes culturales:

a) la adaptación cultural, que consiste en la sustitución de los referentes culturales llegada.

de la cultura de partida por otros equivalentes de la cultura de

b) la traducción explicativa, en la que el traductor explicita una determinada

referencia con el fin de facilitar la comprensión por parte del espectador.

c) la supresión de los elementos que resultan incomprensibles para la cultura meta y su sustitución o no por otros.

d) la no-traducción, siendo esta estrategia la que la autora considera menos recomendable.

Teniendo en cuenta las estrategias propuestas por estos autores, trataremos de analizar los elementos culturales e intertextuales que vayan surgiendo a lo largo de los episodios mencionados. En el caso que nos ocupa, es decir, el subtitulado de una serie estadounidense para una audiencia española, es importante tener en cuenta la gran cantidad de referentes culturales de aquella cultura que ya existen. Como señalábamos anteriormente, el dinamismo inherente a las culturas y el alto porcentaje de 
material audiovisual, procedente de los Estados Unidos, importado por España a lo largo de los años, han desembocado en una situación como la que, según Amando de Miguel (21/07/06), describe Joaquín Sempere,

\begin{abstract}
Desde que las insignias se llaman pins, los maricones gays, las comidas frías lunchs, y los repartos de cine castings, este país no es el mismo: ahora es mucho, muchísimo más moderno. Antaño los niños leían tebeos en vez de comics, los estudiantes pegaban pósters creyendo que eran carteles, los empresarios hacían negocios en vez de business, y los obreros, tan ordinarios ellos, sacaban la fiambrera al mediodía en vez del tupper-ware [...] Evidentemente, no es lo mismo decir bacon que panceta, aunque tengan la misma grasa; ni vestíbulo que hall, ni inconveniente que handicap [...]
\end{abstract}

Al igual que, como indica Sempere, estos préstamos han ido ganando terreno, hay diferentes referentes culturales e intertextuales de la cultura anglosajona que ya conoce gran parte de la audiencia española. El dominio cultural de los productos estadounidenses y británicos sobre las demás culturas resulta evidente ya que, como señala Agost (1999: 100), "muchos europeos no saben el nombre que recibe la moneda marroquí, qué es la fideuá [...] o quién es Fofó. Pero todo el mundo sabe qué es un dólar, una hamburguesa, un MacDonald's o quién es Humphrey Bogart"6. Por tanto, veremos elementos culturales e intertextuales que compartirán ambas culturas y otros que no coincidirán. Por ello, el subtitulador habrá de ser buen conocedor de las lenguas y culturas con las que trabaja. Será el traductor/subtitulador quien tome la decisión de si la alusión a un referente cultural es relevante o no para la interpretación del texto. En este sentido, cobra transcendencia la figura del traductor como mediador intercultural.

Por otro lado, como ya se ha dicho, el traductor/subtitulador debe hacer frente así mismo a otro tipo de consideraciones como la velocidad de lectura, el sincronismo, el número de caracteres por línea, etc. Además, el mecenas y los factores económicos también influirán en el resultado final. En el caso de la serie objeto de este trabajo, es importante destacar lo que asegura Kaplan: "An episode of Friends shown tonight in the United States is seen in 50 other countries as a subtitled or dubbed version, so time is of the essence " (Shadbolt 2003: 38). En efecto, en la mayor parte de los encargos de traducción el tiempo es oro.

\footnotetext{
${ }^{6}$ Snell-Hornby (2006: 129) hace referencia a esta hegemonía cuando describe el fenómeno del McWorld. Este término comenzó a utilizarse a partir de la publicación del artículo de Benjamin Barber, "Jihad vs. McWorld", publicado en en marzo de 1992 por la revista The Atlantic Monthly. En dicho artículo, Barber describe la comercialización internacional y el fundamentalismo como dos de las grandes fuerzas características del siglo XXI.
} 


\section{ANÁLISIS TRADUCTOLÓGICO}

Teniendo en cuenta todo lo expuesto, procedemos a comentar los elementos culturales e intertextuales observados durante el visionado de los episodios de Friends mencionados. (Las referencias se pueden encontrar en los Anexos I y II, con sus números correspondientes)

\subsection{Comidas y bebidas}

1. Cookie? $===>$ ¿Una galleta?

Según el OED cookie: a sweet biscuit.

Adaptación a la lengua meta mediante la generalización, uso de un hiperónimo.

\section{Sweet 'n Low? ===> ¿Sacarina?}

Sweet'n Low (trademarked as Sweet'N Low) is a brand of artificial sweetener from granulated Saccharin, dextrose and cream of tartar. It was invented and first introduced in 1957 by Benjamin Eisenstadt and his son, Marvin Eisenstadt. The elder Eisenstadt had earlier invented the sugar packet, but neglected to patent it, and artificial sweetener packets were an outgrowth of that business. The two were the first to market and distribute the sugar substitute in powdered form. Their distribution company, Cumberland Packing Corporation, still controls the product. The name "Sweet'n Low" itself derives from an 1863 song by Sir Joseph Barnby, which took both its title and lyrics from an Alfred Lord Tennyson poem, entitled The Princess: Sweet and Low. (Wikipedia).

\section{Ice-cream flavours}

Adaptación, generalización, hiperónimo

\subsection{Rocky Road flavour ice-cream ===> de trufa}

Rocky road ice cream is a chocolate flavor, recently ranked tenth in popularity in the United States. Though there are variations on the flavor, it is traditionally composed of chocolate ice cream, nuts and marshmallows. The flavor was created in March 1929 by William Dreyer in Oakland, California when he cut up walnuts and marshmallows with his wife's sewing scissors and added them to his chocolate ice cream in a manner that reflected his partner Joseph Edy's chocolate candy creation incorporating walnuts and marshmallow pieces. Later, the walnuts would be replaced by pieces of toasted almond. After the Wall Street Crash of 1929, the company gave the flavor its current name "to give folks something to smile about in the midst of the Great Depression." Alternately, Fentons Creamery in Oakland, claims that William Dreyer based his recipe on a Rocky Road-style ice cream flavor invented by his friend, Fentons' George Farren, who blended his own Rocky Road-style candy bar into ice cream; however Dreyer substituted almonds for walnuts. 


\section{Rocky Road in popular culture}

Weird Al Yankovic makes a tribute to Rocky Road with his song "I Love Rocky Road", a parody of the Joan Jett song "I Love Rock and Roll". (Wikipedia).

\subsection{Cookie Dough ===> almendrado}

Cookie dough refers to a blend of cookie ingredients which has been mixed into a solid yet malleable form but has not yet been hardened by heat. The dough is often then separated and the portions baked to individual cookies, or eaten as is. Cookie dough often contains chocolate chips. (Wikipedia).

\subsection{Cherry Vanilla ===> de cereza y vainilla}

Este sabor de helado es tan conocido en los Estados Unidos que incluso una compositora y cantante estadounidense se puso este nombre.

En los tres casos, se ha tratado de simplificar los referentes al máximo mediante la adaptación a sabores de helados conocidos en la cultura meta.

\section{Jimmies}

Jimmies: tiny rod-shaped bits of usually chocolate-flavoured candy often sprinkled on ice- cream. (Merriam Webster Dictionary Online)

Omisión del referente

13. spell it out with noodles $===>$ deletrearlo con los fideos

A noodle is food made from unleavened dough that is cooked in a boiling liquid. Depending upon the type, noodles may be dried or refrigerated before cooking. The word noodle derives from the German Nudel (noodle) and may be related to the Latin word nodus (knot). In American English, noodle is a generic term for unleavened dough made from many different types of ingredients. Noodles exist in an abundance of shapes. (Wikipedia).

Adaptación a la cultura meta

\section{Western omelet $===>$ tortilla}

A Denver omelette, also known as a Western omelette, is an omelette filled with diced ham, onions, and green bell peppers, though there are many variations on fillings. Often served in the midwestern United States and sometimes has a topping of cheese and a sidedish of hashbrowns or fried potatoes. (Wikipedia).

Generalización

\section{Curry $===>$ Curry \\ Lasagne $===>$ Lasaña \\ Spaghetti $===>$ Espaguetis}

Referentes culturales gastronómicos compartidos por ambas culturas. 


\subsection{Personajes conocidos}

4. Lincoln High survivor $===>$ superviviente de $\mathrm{mi}$ instituto

Lincoln, Abraham (1809-65). American Republican statesman, $16^{\text {th }}$ President of the US (1861-5). OED.

Omisión del referente.

\section{Mr. Potato Head $===>$ Sr. Patata}

Este juguete, como otros muchos productos, se ha importado a España. Sin embargo, la denominación que se suele emplear es el Sr. Potato.

http://www.toysrus.es/SiteFrontend/catalogue/ProductListBusqueda.a spx

Referente existente en la cultura española.

\section{Pinocchio $===>$ Pinocho}

Pinocho (en italiano Pinocchio) es la marioneta de madera protagonista del libro La aventura de Pinocho escrito por Carlo Collodi y publicado en Italia en un periódico desde 1882 hasta 1883, con los títulos "Storia di un burattino" (Historia de un títere) y "Le aventure di Pinocchio" (La aventura de Pinocho), ilustradas por Enrico Mazzanti. Este personaje tuvo una enorme difusión. La primera versión en español, que corrió a cargo de Rafael Calleja, hijo del fundador de la Editorial Calleja e ilustrado por Salvador Bartolozzi en una adaptación más castiza de la novela.

Se ha convertido en un clásico de la literatura infantil y se han realizado más de veinte películas, entre las que se incluyen la realización de dibujos animados de Disney del año 1940, la película de Luigi Comencini de 1972 y el film del año 2002 dirigido y protagonizado por Roberto Benigni. La película animada de Disney, aunque es una adaptación libre de la historia de Collodi, es considerada una pieza maestra dentro de la animación y ha sido designada como "culturalmente importante" por la biblioteca del Congreso de los Estados Unidos, y fue seleccionada para su preservación en el Registro de Películas del mencionado país.

En este caso se trata de un referente cultural compartido por ambas culturas.

\section{Liza Minelli $===>$ Liza Minelli}

Cantante y actriz estadounidense.

Se ha mantenido el referente, pero quizás no todos los espectadores conocerán a Lizza Minelli.

\section{Pink Floyd $===>$ Pink Floyd}

Pink Floyd fue un grupo de rock británico que cosechó gran popularidad gracias a su música psicodélica, la cual, con el paso del tiempo, fue evolucionando hacia el rock progresivo y el rock sinfónico. Es conocido por sus canciones de contenido filosófico, la experimentación sónica, las innovadoras portadas de sus discos y sus elaborados espectáculos en vivo. 
Es una de las bandas más importantes de la escena del rock con más de 200 millones de álbumes vendidos en todo del mundo, 74,5 millones de ellos sólo en los Estados Unidos. (Wikipedia)

En este caso, también se ha mantenido el referente $y$, si bien es cierto que, por lo general, los espectadores españoles no tendrán dificultades para entender la relación, dependerá del grupo de edad.

Este referente vuelve a aparecer de manera indirecta unas líneas más abajo

that album ===> ese albúm

29. Minnie Mouse $===>$ Minnie Mouse

Minnie Mouse es un personaje de dibujos animados de los Estudios Disney.

Referente cultural compartido.

2.3. Alusiones a canciones conocidas

9. Raindrops on roses

and rabbits and kittens,

bluebells and sleighbells

en and- something with mittens...

La la la la...something

with string...

\author{
$===>$ Gotas de lluvia en las rosas \\ Bigotes en los gatos \\ Timbres y cascabeles y no sé que \\ los platos \\ La, La, La no sé qué \\ $Y$ fideos con cuerdas
}

Raindrops on roses and whiskers on kittens

Bright copper kettles And warm woolen mittens

Brown paper packages Tied up with strings

These are a few of my favorite things (My Favourite Things en la película The Sound of Music)

Se trata de un fragmento de una de las canciones de la película The Sound of Music (1965), interpretada por Julie Andrews. Como podemos ver, Phoebe cambia diferentes partes de la canción y resulta muy gracioso. Sin embargo, en la versión castellana tanto la subtitulada como la doblada produce más bien extrañeza.

14. Do the words 'Billy, don't be a hero' $===>$ ¿Os suena la frase mean anything to you?

"No te hagas el héroe"?

"Billy Don't Be a Hero" is a 1974 anti-war pop song by Paper Lace and was also recorded by Bo Donaldson and the Heywoods. It was written by Mitch Murray and Peter Callander.

Because the song was released in 1974, it is often associated with the Vietnam War, though it may also refer to the American Civil War as evidenced by the "soldier blues" (the Union Forces) in the lyrics. A young 
woman is distraught that her fiancé chooses to leave the area with an Army contingent passing through the town and go with them to fight. She laments,

"Billy, don't be a hero! Don't be a fool with your life!

"Billy, don't be a hero! Come back and make me your wife!

"And as he started to go, she said, 'Billy, keep your head low!'

"Billy, don't be a hero! Come back to me!"

The song goes on to describe how Billy is killed in action in a pitched battle after volunteering to ride out and seek reinforcements. In the end, the woman throws away the regret letter notifying her of Billy's "heroic" death. (Wikipedia)

Se ha hecho una traducción del referente, pero al espectador le falta el bagaje informativo necesario para entender el toque humorístico.

25. I was in the kitchen with...

Dinah? ===>

I've been working on the railroad All the live-long day.

I've been working on the railroad Just to pass the time away.

Don't you hear the whistle blowing,

Rise up so early in the morn;

Don't you hear the captain shouting,

"Dinah, blow your horn!"

Dinah, won't you blow,

Dinah, won't you blow,

Dinah, won't you blow your horn?

Dinah, won't you blow,

Dinah, won't you blow,
¿Dinah?

Dinah, won't you blow your horn?

Someone's in the kitchen with Dinah Someone's in the kitchen I know Someone's in the kitchen with Dinah Strummin' on the old banjo!

Singin' fi, fie, fiddly-i-o

$\mathrm{Fi}$, fie, fiddly-i-o-o-o-o

$\mathrm{Fi}$, fie, fiddly-i-o

Strummin' on the old banjo.

Someone's makin' love to Dinah

Someone's making love I know.

Someone's making love to Dinah

Cause I can't hear the old banjo

"I've Been Working on the Railroad" is an American folk song. The first published version appeared as "Levee Song" in Carmina Princetonia, a book of Princeton University songs published in 1894. ${ }^{[1]}$ The earliest known recording is by the Sandhills Sixteen, released by Victor Records in 1927.

The "Someone's in the kitchen with Dinah" section is actually an older song that has been absorbed by "I've Been Working on the Railroad". It was published as "Old Joe, or Somebody in the House with Dinah" in London in the 1830 s or "40s, with music credited to J.H. Cave. ${ }^{[9]}$ "Dinah" was a generic name for an enslaved African woman. ${ }^{[10]}$ The melody for this section of the song may have been adapted from "Good Night Ladies", written (as "Farewell Ladies") in 1847 by E. P. Christy. (Wikipedia) 
Se ha mantenido el referente, pero si no se conoce la información que sustenta el toque humorístico, el espectador tendrá la sensación de que "se ha perdido algo".

\subsection{Lugares}

6. this really gorgeous Limoges gravy boat $===>$ una salsera realmente preciosa

Limoges: a city in west central France, the principal city of Limousin. Famous in the late Middle Ages for enamel work, it has been noted since the $18^{\text {th }}$ century for the production of porcelain. OED

Basta hacer una búsqueda en Google para ver que en la cultura americana ese tipo de porcelana es muy conocida.

Omisión del referente

10. Aruba $===>$ Aruba

Aruba: an island in the Caribbean Sea, close to the Venezuelan coast. (OED)

En Estados Unidos se trata de un conocido destino de luna de miel, pero quizás aquí no se haga esa conexión de manera automática.

Se mantiene el referente

17. Florida $===>$ Florida

Referente cultural compartido (ver punto 3)

19. Las Vegas $===>$ Las Vegas

Referente compartido (ver punto 3).

2.5. Alusiones a programas de $t v$, anuncios, marcas y películas conocidas

5 . are we waiting for four wet bridesmaids? $===>$ ¿esperamos a tus damas de honor?

Referencia a la película británica Four Weddings and a Funeral dirigida por Mike Newell en 1994.

Omisión del referente

\section{John and David boots $===>$ estas botas}

JOHN DAVID SHOES

Established 1989

This specialized shoe store caters to a wide age range with customers and friends from seventeen to ninety-four years of age. John's lifelong love for the shoe business combined with John David Shoes' extensive selection of stylish and quality products has created success and longevity.

John David Shoes has found it's niche, that being fashion footwear for women of all ages. John Ingram (owner) and Jill Hackett (manager) combined bring over forty-five years of experience to the footwear industry to create a unique shopping experience at John David.

$<$ http://www.johndavidshoes.ca/> 
Omisión del referente.

22. Three's Company $===>$ Apartamento para tres

Three's Company is an American sitcom that aired from 1977 to $\underline{1984}$ on $\underline{A B C}$. It is a remake of the British sitcom Man About the House. The story revolves around three roommates, Janet Wood, Chrissy Snow (later Cindy Snow and Terri Alden), and Jack Tripper who share Apartment 201 in a Santa Monica apartment building owned by Mr. and Mrs. Roper (later owned by Bart Furley but managed by his brother, Ralph Furley). The show chronicles the escapades of the trio's constant misunderstandings, social lives, and struggle to keep up with rent. (Wikipedia)

Como en otros muchos casos, la hegemonía de la industria audiovisual estadounidense queda patente en la existencia de este tipo de referentes en otras culturas.

\section{Thighmaster $===>$ hace gimnasia}

The Thighmaster is an exercise product designed to shape one's thighs. The device is basically two pieces of metal tube bent in a loop and connected with a hinge. The intended use is to put the Thighmaster between the knees and squeeze them together. This exercises the hip adductors. Even if the marketing was targeted towards women (assuming men rarely want to shape their legs), the simple mechanism allows exercising any suitable muscle where a small angle can be created to press it, for example the biceps (elbow flexion) or the hamstrings (knee flexion). (Wikipedia)

Omisión del referente por medio de una paráfrasis.

\subsection{Expresiones}

\section{Strip joint! ===> ¡Ir a un striptease!}

Strip joint: noun (slang)- a nightclub or other establishment featuring striptease performances. (Dictionary.com).

Se ha adaptado el término mediante una paráfrasis y el empleo de un anglicismo (en cursiva) asentado en la lengua castellana.

\section{Doy $===>$ jolines}

Kind of means "Wasn't that obvious, huh?", similar to duh

Another way of saying "no kidding"

Pointing out that something said by another was painfully obvious

http://www.urbandictionary.com/define.php?term=doy castellano.

Se ha sustituido por una expresión con connotaciones similares en

\subsection{Unidades monetarias}

\section{3. a million dollars $===>$ un millón de dólares}

Uso de la traducción oficial, no hace falta ningún tipo de explicación ya que, como hemos visto con Agost (1999: 100), "muchos europeos no 
saben el nombre que recibe la moneda marroquí, qué es la fideuá [...] o quién es Fofó. Pero todo el mundo sabe qué es un dólar, una hamburguesa, un MacDonald's o quién es Humphrey Bogart".

28. Forty thousand dolars $===>\mathbf{4 0 . 0 0 0}$ (ver punto 3 )

\subsection{Otros referentes}

27. club $===>$ club

Sociedad fundada por un grupo de personas con intereses comunes y dedicada a actividades de distinta especie, principalmente recreativas, deportivas o culturales. (RAE)

Referente asentado en la lengua castellana

\section{0. the Enterprise $===>$ el Enterprise}

Two ships of the Continental Navy were named Enterprise:

USS Enterprise (1775) armed sloop (May 181775 - July 7 1777), the first American ship to bear the name, she served on Lake Champlain

Enterprise (1776) schooner (December 201776 - February 1777), the second American ship to bear this name, she served on Chesapeake Bay (Wikipedia).

Six ships of the United States Navy have been named Enterprise

Se ha mantenido el referente $y$, para un espectador español, puede resultar extraño.

\section{CONCLUSIONES}

Como se puede observar en los diferentes ejemplos analizados, parece que las estrategias más empleadas, aunque no en todos los casos, son la generalización y la omisión de los referentes culturales e intertextuales desconocidos. De está manera, se ofrece una traducción aceptable $^{7}$, en términos de Toury, mediante la simplificación de los elementos específicos, desconocidos, propios de la cultura fuente. Podríamos preguntarnos si realmente merece la pena mantener ciertos nombres propios, eventos o instituciones que no resultan conocidos para la audiencia meta, ya que, sin el bagaje informativo necesario, no es posible lograr una comprensión de la situación por parte del espectador. ¿Qué es peor, dejar una referencia inalterada o sustituirla por elementos, ya sea personas, lugares o cosas, propias de la cultura meta? En mi opinión, en una serie como Friends, ambientada en Nueva York y cuyos capítulos se desarrollan en el Central Perk (cerca de Central Park) por dónde pasan taxis

\footnotetext{
${ }^{7}$ Toury hace una distinción entre traducciones aceptables y adecuadas. Las primeras se rigen por las normas de la cultura término, mientras que las segundas se adaptan a las normas de la cultura origen.
} 
amarillos, una referencia al helado de turrón (punto 11) o a Norma Duval (punto 20) quedaría fuera de lugar.

Dicho esto, es necesario tener en cuenta que varios de los referentes que aparecen en los capítulos como dólar, Las Vegas, Pink Floyd o Apartamento para tres se han mantenido en los subtítulos en castellano y, dado que están asentados en la cultura española, no dificultan en absoluto la comprensión por parte del espectador. La hegemonía de Estados Unidos en la industria audiovisual queda patente en la cantidad de elementos culturales específicos de la cultura estadounidense que han pasado a formar parte de otras culturas, entre ellas la española.

En cuanto a las soluciones de subtitulado ofrecidas para casos como la canción (punto 9) y la expresión "Billy don't be a hero" (punto 14) o Dinah (punto 25), no resultan convincentes para los espectadores españoles a los que he consultado ya que realmente "no les hace gracia", simplemente provoca extrañeza. El humor es, sin duda, uno de los elementos que más dificultades engloba para el traductor debido a su naturaleza cultural. Tanto en la producción como en la consiguiente interpretación del mismo es indispensable un conocimiento cultural compartido; de lo contrario, la traducción del humor en gran parte de las ocasiones implicará la pérdida de la carga humorística. En este sentido, apunta Leppihalme (1997: 104-105) que:

The translator has not recognised that many allusions are not superfluous elements in the text but interwoven in its texture to such an extent that their loss, through undertranslation, may be a severe one [...] The problem with minimum change translations- sometimes avoidable, sometimes not- is not just that they do not always do justice to the ST author's skill [...] The true problem, from my point of view, is that minimum change does not always enable the TT reader to participate in the creative process, picking up associations and interpreting in his/her own way what was only half-said in the text at hand.

Dependiendo del enfoque traductológico que se adopte, se puede hablar del subtitulado como traducción o como adaptación. Es decir, desde un enfoque prescriptivista no se considera traducción ya que las estrategias de omisión, la neutralización, la naturalización, y otra clase de modificaciones que hemos visto, impiden la reproducción "exacta" del texto fuente. No favorecen la transmisión literal y fie/ del original. Por otro lado, los modelos descriptivistas incluyen esta modalidad como un tipo de traducción si responde a los criterios de aceptabilidad del contexto meta. En este sentido, para lograr esa aceptabilidad de la audiencia receptora será necesario llevar a cabo una serie de estrategias traductológicas para favorecer la transmisión del contenido. 
Como veíamos anteriormente, la serie Friends se prepara simultáneamente para varios mercados y culturas diferentes. Y, si consideramos que "one of the defining characteristics of subtitling as compared with other types of translation is the limitation in space, which comes from the medium, and time imposed by the nature of the audiovisual content" (O'Hagan 2007:158), podemos entender la naturaleza de las omisiones y generalizaciones que abundan en los subtítulos. En este sentido, en el que, por razones comerciales, se tiende a simplificar el producto y a adaptarlo a la audiencia receptora parece que el apartado de O'Hagan (id) titulado "From Screen Translation to Localization" es aplicable. Según Montalt (2003: 322), "la localización confirma el mayor extremo de la teoría del Skopos: todo, absolutamente todo, está en función del receptor meta [...] no está concebida para salvaguardar la diversidad lingüística y cultural".

Michael Cronin (2003: 17), por su parte, nos hace reflexionar sobre las consideraciones culturales en el mercado actual en el que la globalización y los plazos restringidos forman parte del día a día del traductor, " $[\mathrm{H}]$ ow does the increased anesthetization of goods, informational or otherwise, tally with the globalization of their distribution and do translators have to sacrifice cultural nuance to customer deadlines?". En el caso que nos ocupa, parecería que los referentes que se han mantenido no son óbice para la comprensión del receptor español, salvo casos excepcionales. Los que podrían suponer un obstáculo (cultural bump ${ }^{8}$ ) se han generalizado 0 , simplemente, se han eliminado y los elementos humorísticos se han traducido tal cual, sin tener en cuenta la necesidad de un bagaje cultural preciso para su interpretación. Como resultado, podríamos decir que se consigue un texto que puede ayudar a seguir el argumento de la serie sin problemas para una audiencia que no domina la lengua inglesa o servir de apoyo didáctico en el aprendizaje de idiomas. Sin embargo, para una audiencia interesada en las consideraciones culturales, el texto resulta demasiado neutro. Sin duda, el espectador debe ser consciente de las limitaciones que rodean a este tipo de traducción.

En el ámbito de la subtitulación de estos productos resulta complicado defender que la solución a todos los referentes culturales y humorísticos no puede o debe reducirse siempre a la simple omisión y neutralización. Como afirma Leppihalme (1997: 103), "[A] translator will not be motivated to consider different strategies if $\mathrm{s} / \mathrm{he}$ is content to leave obscurities in the text [...] Lack of time and/or financial incentive could perhaps also sometimes be a factor". A pesar de las consideraciones postcoloniales a este respecto, el mercado audiovisual se caracteriza por la

${ }^{8}$ Leppihalme 1997 
inmediatez y los plazos restringidos. De esta manera, parecería que, en muchos casos, ni la extranjerización ni la domesticación reciben especial atención mientras el contenido llegue medio bien y, sobre todo, a tiempo. En palabras de Barber (1992: 55),

\begin{abstract}
If the automobile was, as George Ball once said [...] "an ideology on four wheels", then electronic telecommunication and information systems are an ideology at 186,000 miles per second-which makes for a very small planet in a very big hurry. Individual cultures speak particular languages; commerce and science increasingly speak English; the whole world speaks logarithms and binary mathematics.
\end{abstract}

REFERENCIAS BIBLIOGRÁFICAS

AGost, Rosa (1999) Traducción y doblaje: palabras, voces e imágenes (Barcelona: Ariel).

BAKER, Mona (2001) (ed.) Routledge Encyclopedia of Translation Studies (London and New York: Routledge).

(2006) Translation and Conflict (London and New York: Routledge).

BARBER, Benjamin R. (1992) "Jihad vs. Mc World", The Atlantic Monthly, Vol. 269, No. 3, 53-65. Disponible en http://www.theatlantic.com/doc/199203/barber (consultado 1/04/2009)

BASSNETT, Susan (2002 [1980]) Translation Studies (London and New York: Routledge).

y André LefeVere, (1990) (eds.) Translation, History and Culture (London and New York: Printer Publishers).

BASSNETT, Susan y André LefEVERE (1998) (eds.) Constructing Cultures. Essays on Literary Translation (Clevedon: Multilingual Matters).

CRONIN, Michael (2003) Translation and Globalization, (London and New York: Routledge).

DE MIGUEL, Amando (2006) "El lenguaje como presentación", Libertad Digital (21/07/2006). Disponible en http://www.libertaddigital.com/opinion/amando-de-miguel/el-lenguajecomo-presentacion-32464/ (Consultado 18/04/2009)

DíAZ CINTAS, Jorge (2001) La traducción audiovisual: el subtitulado (Salamanca: Ediciones Almar). (2003) "Audiovisual Translation in the Third Millennium", en Gunilla Anderman y Margaret Rogers (eds.), Translation Today. Trends and Perspectives (Clevedon: Multilingual Matters Ltd).

GENTZLER, Edwin (2001) Contemporary Translation Theories (Clevedon: Multilingual Matters Ltd).

HATIM, Basil e lan MASON (1997) The Translator as Communicator (Manchester: St. Jerome Publishing). 
HeRmans, Theo (1985) (ed.) The Manipulation of Literature: Studies in Literary Translation (London: Routledge).

(1999) Translation in Systems. Descriptive and System-oriented Approaches Explained (Manchester: St. Jerome Publishing). (2007) The Conference on the Tongues (Manchester/Kinderhook: St. Jerome Publishing).

HoLmES, James S. (1972) "The Name and Nature of Translation Studies", en James S. HOLMES (1994) (ed.), 67-80.

(1978) "The Future of Translation Theory: A Handful of Theses", en Holmes, James S. (1994) (ed.), 99-102.

(1994) (ed.) Translated! Papers on Literary Translation and Translation Studies (Amsterdam: Rodopi).

JAKOBSON, Roman (1959) "On Linguistic Aspects of Translation", en Venuti 2006 [2000] (ed.), 138-143.

LefEVERE, André (1985) "Why Waste Our Time on Rewrites? The Trouble with Interpretation and the Role of Rewriting in an Alternative Paradigm", en Hermans (ed) (1985), 215-243.

(1992) Translation, Rewriting and the Manipulation of Literary Fame (London: Routledge).

LePPIHALME, Ritva (1997) Culture Bumps. An Empirical Approach to the Translation of Allusions (Clevedon: Multilingual Matters Ltd).

MONTALT, Vicent (2003) "La traducción de géneros electrónicos: el caso de la localización", en Miguel Ángel GARCíA PEINADO y Emilio Ortega ARJONILLA (coords.) Panorama actual de la investigación en traducción e interpretación, vol. II, parte II, Sección III, 313-328.

MOYA, Virgilio (2004) La selva de la traducción. Teorías traductológicas contemporáneas (Madrid: Ediciones Cátedra).

MundAY, Jeremy (2001) Introducing Translation Studies. Theories and Applications (London and New York: Routledge).

NidA, Eugene A. y Charles R. TABER (1982 [1969]) The Theory and Practice of Translation (Leiden: Brill).

O'HAGAN, Minako (2007) "Impact of DVD on Translation. Language Options as an Essential Add-On Feature", Convergence: The International Journal of Research into New Media Technologies, Vol 13, №2, 157168.

Orero, Pilar (2004) (ed.) Topics in Audiovisual Translation (Amsterdam/ Philadelphia: John Benjamins).

Pedersen, Jan (2005) "How is Culture Rendered in Subtitles?", en Heidrun Gerzymisch-Arbogast y Sandra Nauert (eds.) MuTra: Challenges of Multidimensional Translation-Saarbrücken 2-6 May 2005,

Proceedings (Saarbrücken: Saarland University), 113-130. 
SHADBOLT, David (2003) "Localizing Movies and Broadcasting", Multilingual Computing and Technology (Diciembre 2003), Vol. 14, №8, 37-40.

SNELL-HORNBY, Mary (1988) Translation Studies: An Integrated Approach (Amsterdam/ Philadelphia: John Benjamins). (1990) "Linguistic Transcoding or Cultural Transfer? A Critique of Translation Theory in Germany", en Bassnett y Lefevere 1990 (eds.), 79-86.

(2006) The Turns of Translation Studies (Amsterdam: John Benjamins)

TITFORD, C (1982) "Subtitling-Constrained Translation", Lebende Sprachen, Vol. XXVII, №3, 113-116.

TOURY, Gideon (1995) Descriptive Translation Studies and beyond (Amsterdam: John Benjamins).

TYMOCZKO, Maria (2007) Enlarging Translation, Empowering Translators (Manchester and Kinderhook: St. Jerome Publishing).

y Edwin GeNTZLER (2002) (eds.) Translation and Power (Amherst and Boston: University of Massachusetts Press).

VENUTI, Lawrence (1992) (ed.) Rethinking Translation. Discourse, Subjectivity, Ideology (London and New York: Routledge).

VENUTI, Lawrence (1995) The Translator's Invisibility. A History of Translation (London and New York: Routledge). (1998a) The Scandals of Translation: Towards an Ethics of Difference (London and New York: Routledge).

VINAY, Jean-Paul y Jean DARBELNET (1977 [1958]) Stylistique comparée du français et de l'anglais (Paris: Didier).

ZABALBEASCOA, Patrick, Laura SANTAMARIA y Federic ChaUme (2005) (eds.) La traducción audiovisual. Investigación, enseñanza y profesión (Granada: Comares).

DVD

Friends. Temporada1 - Disco1 - Episodios 1 a 6. Warner Bros. Entertainment Inc. 2003. Distribuida en España por Warner Home Video Española, S.A 


\section{ANEXO I}

Nota: estos son los diálogos del DVD Temporada 1, Disco 1 Episodios 1-6, de Warner Bross Entertainment Inc. Distribuido en España por Warner Home Video Española. Existen otras versiones de este mismo capítulo.

The One Where Monica Gets a New Roommate - a.k.a. The One Where It All Began (The Pilot-The Uncut Version)

--Written by: Marta Kauffman \& David Crane

Transcribed by: guineapig

Additional transcribing by: Eric Aasen

--[Scene: Central Perk, Chandler, Joey, Phoebe, and Monica are there.] Monica: There's nothing to tell! It's just some guy I work with!

Joey: C'mon, you're going out with the guy! There's gotta be something wrong with him!

Chandler: So does he have a hump?

A hump and a hairpiece?

Phoebe: Wait, does he eat chalk?

(They all stare, bemused.)

Phoebe: Just, 'cause, I don't want her to go through what I went through with Carl- oh!

Monica: Okay, everybody relax. This is not even a date. It's just two people going out to dinner and- not having sex.

Chandler: Sounds like a date to me.

[Time Lapse]

Chandler: Alright, so I'm back in high school, I'm standing in the middle of the cafeteria, and I realize I am totally naked.

All: Oh, yeah. Had that dream.
Chandler: Then I look down, and I realize there's a phone... there.

Joey: Instead of...?

Chandler: That's right.

Joey: Never had that dream.

Phoebe: No.

Chandler: All of a sudden, the phone starts to ring. Now I don't know what to do, everybody starts looking at me.

Monica: And they weren't looking at you before?!

Chandler: Finally, I figure l'd better answer it, and it turns out it's my mother, which is very-very weird, because- she never calls me! [Time Lapse, Ross has entered.] Ross: (mortified) Hi.

Joey: This guy says hello, I wanna kill myself.

Monica: Are you okay, sweetie?

Ross: I just feel like someone reached down my throat, grabbed my small intestine, pulled it out of my mouth and tied it around my neck...

Chandler: Cookie'?

Monica: (explaining to the others) Carol moved her stuff out today. Joey: Ohh. Monica: (to Ross) Let me get you some coffee.

Ross: Thanks.

Phoebe: Ooh! Oh! (She starts to pluck at the air just in front of Ross.)

Ross: No, no don't! Stop cleansing my aura! No, just leave my aura alone, okay?

Phoebe: Fine! Be murky!

Ross: I'll be fine, alright? Really, everyone. I hope she'll be very happy.

Monica: No you don't. 
Ross: No I don't, to hell with her, she left me!

Joey: And you never knew she was a lesbian...

Ross: No!! Okay?! Why does everyone keep fixating on that? She didn't know, how should I know?

Chandler: Sometimes I wish I was a lesbian... (They all stare at him.) Did I say that out loud?

Joey: Alright Ross, look. You're feeling a lot of pain right now. You're angry. You're hurting. Can I tell you what the answer is?

(Ross gestures his consent.)

Joey: Strip joint'! C'mon, you're single! Have some hormones!

Ross: I don't want to be single, okay? I just... I just- I just wanna be married again!

(Rachel enters in a wet wedding dress and starts to search the room.)

Chandler: And I just wanna a million dollars ${ }^{3 !}(\mathrm{He}$ extends his hand hopefully.)

Monica: Rachel?!

Rachel: Oh God Monica hi! Thank God! I just went to your building and you weren't there and then this guy with a big hammer said you might be here and you are, you are!

Waitress: Can I get you some coffee? Monica: (pointing at Rachel) De-caff. (to All) Okay, everybody, this is Rachel, another Lincoln High survivor ${ }^{4}$ (to Rachel) This is everybody, this is Chandler, and Phoebe, and Joey, and- you remember my brother Ross?

Rachel: Hi, sure!

Ross: Hi.

(They go to hug but Ross's umbrella opens. He sits back down defeated again. A moment of silence follows as Rachel sits and the others expect her to explain.)
Monica: So you wanna tell us now, or are we waiting for four wet bridesmaids ${ }^{5}$ ?

Rachel: Oh God... well, it started about a half hour before the wedding. I was in the room where we were keeping all the presents, and I was looking at this gravy boat. This really gorgeous Limoges gravy boat ${ }^{6}$. When all of a sudden- (to the waitress that brought her coffee) Sweet 'n Low? - I realized that I was more turned on by this gravy boat than by Barry! And then I got really freaked out, and that's when it hit me: how much Barry looks like Mr. Potato Head'. Y'know, I mean, I always knew looked familiar, but... Anyway, I just had to get out of there, and I started wondering 'Why am I doing this, and who am I doing this for?'. (to Monica) So anyway I just didn't know where to go, and I know that you and I have kinda drifted apart, but you're the only person I knew who lived here in the city. Monica: Who wasn't invited to the wedding.

Rachel: Ooh, I was kinda hoping that wouldn't be an issue... [Scene: Monica's Apartment, everyone is there and watching a Spanish Soap on TV and are trying to figure out what is going on.]

Monica: Now I'm guessing that he bought her the big pipe organ, and she's really not happy about it.

Rachel: (on phone) Daddy, I just... I can't marry him! I'm sorry. I just don't love him. Well, it matters to me!

Chandler: (re TV) Ooh, she should not be wearing those pants.

Joey: I say push her down the stairs. 
Phoebe, Ross, Chandler, and Joey: Push her down the stairs! Push her down the stairs! Push her down the stairs!

(She is pushed down the stairs and everyone cheers.)

Rachel: C'mon Daddy, listen to me! It's like, it's like, all of my life, everyone has always told me, 'You're a shoe! You're a shoe, you're a shoe, you're a shoe!'. And today I just stopped and I said, 'What if I don't wanna be a shoe? What if I wanna be a- a purse, y'know? Or a- or a hat! No, I'm not saying I want you to buy me a hat, I'm saying I am a ha- It's a metaphor, Daddy!

Ross: You can see where he'd have trouble.

Rachel: Look Daddy, it's my life. Well maybe I'll just stay here with Monica.

Monica: Well, I guess we've established who's staying here with Monica...

Rachel: Well, maybe that's my decision. Well, maybe I don't need your money. Wait!! Wait, I said maybe!!

[Time Lapse, Rachel is breathing into a paper bag.]

Monica: Just breathe, breathe.. that's it. Just try to think of nice calm things... Phoebe: (sings) Raindrops on roses and rabbits and kittens, (Rachel and Monica turn to look at her.) bluebells and sleighbells and- something with mittens... La la la la...something with string...

Rachel: I'm all better now.

Phoebe: (grins and walks to the kitchen and says to Chandler and Joey.) I helped!

Monica: Okay, look, this is probably for the best, y'know? Independence. Taking control of your life.
Joey: (comforting her) And hey, you need anything, you can always come to Joey. Me and Chandler live across the hall. And he's away a lot.

Monica: Joey, stop hitting on her! It's her wedding day!

Joey: What, like there's a rule or something?

(The door buzzer sounds and Chandler gets it.)

Chandler: Please don't do that again, it's a horrible sound.

Paul: (over the intercom) Uh it's, uh, it's Paul.

Monica: Buzz him in!

Joey: Who's Paul?

Ross: Paul the Wine Guy, Paul?

Monica: Maybe.

Joey: Wait a minute. Your 'not a real date' tonight is with Paul the Wine Guy?

Ross: He finally asked you out?

Monica: Yes!

Chandler: Ooh, this is a Dear Diary moment.

Monica: Rach, wait, I can cancel...

Rachel: Please, no, go, l'll be fine!

Monica: (to Ross) Are, are you okay? I mean, do you want me to stay?

Ross: (choked voice) That'd be good...

Monica: (horrified) Really?

Ross: (normal voice) No, go on! It's Paul the Wine Guy!

(There's a knock on the door and it's Paul.)

Monica: Hi, come in! Paul, this is..

(They are all lined up next to the door.)... everybody, everybody, this is Paul.

All: Hey! Paul! Hi! The Wine Guy! Hey! 
Chandler: I'm sorry, I didn't catch your name. Paul, was it?

Monica: Sit down. (Shows Paul in) Two seconds.

Phoebe: Ooh, I just pulled out four eyelashes. That can't be good.

(Monica goes to change.)

Ross: So Rachel, what're you, uh... what're you up to tonight?

Rachel: Well, I was kinda supposed to be headed for Aruba ${ }^{10}$ on my honeymoon, so nothing!

Ross: Right, you're not even getting your honeymoon, God.. No, no, although, Aruba, this time of year... talk about your- (thinks) -big lizards... Anyway, if you don't feel like being alone tonight, Joey and Chandler are coming over to help me put together my new furniture.

Chandler: (deadpan) Yes, and we're very excited about it.

Rachel: Well actually thanks, but I think I'm just gonna hang out here tonight. It's been a long day.

Ross: Oh, sure. Okay, sure. Joey: Hey Pheebs, you wanna help? Phoebe: Oh, I wish I could, but I don't want to.

[Scene: Ross's Apartment, the guys are there assembling furniture.]

Ross: (squatting and reading the instructions) I'm supposed to attach a brackety thing to the side things, using a bunch of these little worm guys. I have no brackety thing, I see no whim guys whatsoever and- I cannot feel my legs.

(Joey and Chandler are finishing assembling the bookcase.)

Joey: (picking up a leftover part) What's this?

Chandler: I have no idea.

(Joey checks that Ross is not looking and dumps it in a plant.)

Joey: Done with the bookcase!

Chandler: All finished!
Ross: (clutching a beer can and sniffing) This was Carol's favorite beer. She always drank it out of the can, I should have known.

Joey: Ross, let me ask you a question. She got the furniture, the stereo, the good TV- what did you get?

Ross: You guys.

Chandler: Oh, God.

Joey: You got screwed.

Chandler: Oh my God!

[Scene: A Restaurant, Monica and

Paul are eating.]

Monica: Oh my God!

Paul: I know, I know, I'm such an idiot. I guess I should have caught on when she started going to the dentist four and five times a week. I mean, how clean can teeth get? Monica: My brother's going through that right now, he's such a mess. How did you get through it?

Paul: Well, you might try accidentally breaking something valuable of hers, say her-

Monica: -leg?

Paul: (laughing) That's one way! Me, I- I went for the watch.

Monica: You actually broke her watch? [Scene: Monica's Apartment, Rachel is talking on the phone and pacing.]

Rachel: Barry, I'm sorry... I am so sorry... I know you probably think that this is all about what I said the other day about you making love with your socks on, but it isn't... it isn't, it's about me, and I ju- (She stops talking and dials the phone.) $\mathrm{Hi}$, machine cut me off again... anyway... [Scene: Ross's Apartment; Ross is pacing while Joey and Chandler are working on some more furniture.]

Ross: You know what the scariest part is? What if there's only one 
woman for everybody, y'know? I mean what if you get one woman- and that's it? Unfortunately in my case, there was only one woman- for her...

Joey: What are you talking about? 'One woman'? That's like saying there's only one flavor of ice cream for you. Lemme tell you something, Ross. There's lots of flavors out there. There's Rocky Road, and Cookie Dough, and Bing! Cherry Vanilla ${ }^{11}$. You could get 'em with Jimmies ${ }^{12}$, or nuts, or whipped cream! This is the best thing that ever happened to you! You got married, you were, like, what, eight? Welcome back to the world! Grab a spoon!

Ross: I honestly don't know if I'm hungry or horny.

Chandler: Stay out of my freezer! [Scene: A Restaurant, Monica and Paul are still eating.]

Paul: Ever since she walked out on me, I, uh...

Monica: What?.... What, you wanna spell it out with noodles ${ }^{13}$ ?

Paul: No, it's, it's more of a fifth date kinda revelation.

Monica: Oh, so there is gonna be a fifth date?

Paul: Isn't there?

Monica: Yeah... yeah, I think there is. -

What were you gonna say?

Paul: Well, ever-ev-... ever since she left me, um, I haven't been able to, uh, perform. (Monica takes a sip of her drink.) ...Sexually.

Monica: (spitting out her drink in shock) Oh God, oh God, I am sorry... I am so sorry...

Paul: It's okay...

Monica: I know being spit on is probably not what you need right now. Um... how long?

Paul: Two years.
Monica: Wow! I'm-I'm-I'm glad you smashed her watch!

Paul: So you still think you, um... might want that fifth date?

Monica: (pause)...Yeah. Yeah, I do.

[Scene: Monica's Apartment, Rachel is watching Joanne Loves Chaci.]

Priest on TV: We are gathered here today to join Joanne Louise Cunningham and Charles, ChachiChachi-Chachi, Arcola in the bound of holy matrimony.

Rachel: Oh...see... but Joanne loved Chachi! That's the difference! [Scene: Ross's Apartment, they're all sitting around and talking.]

Ross: (scornful) Grab a spoon. Do you know how long it's been since I've grabbed a spoon? Do the words 'Billy, don't be a hero' mean anything to you?

Ross: Y'know, here's the thing. Even if I could get it together enough to- to ask a woman out,... who am I gonna ask? (He gazes out of the window.)

[Cut to Rachel staring out of her window.]

[Scene: Monica's Apartment, Rachel is making coffee for Joey and Chandler.]

Rachel: Isn't this amazing? I mean, I have never made coffee before in my entire life.

Chandler: That is amazing.

Joey: Congratulations, while you're on a roll, if you feel like you gotta make like a Western omelet ${ }^{15}$ or something... (Joey and Chandler taste the coffee, grimace, and pour it into a plant pot.) Although actually I'm really not that hungry... 
Monica: (entering)

All: Morning. Good morning.

Paul: (entering from Monica's room) Morning.

Joey: Morning, Paul.

Rachel: Hello, Paul.

Chandler: Hi, Paul, is it?

(Monica and Paul walk to the door and talk in a low voice so the others can't hear. The others move Monica's table closer to the door so that they can.)

Paul: Thank you! Thank you so much! Monica: We'll talk later.

Paul: Yeah. (They kiss) Thank you. (Exits)

Joey: That wasn't a real date?! What the hell do you do on a real date?

Monica: Shut up, and put my table back.

All: Okayyy! (They do so.)

Chandler: All right, kids, I gotta get to work. If I don't input those numbers,... it doesn't make much of a difference...

Rachel: So, like, you guys all have jobs?

Monica: Yeah, we all have jobs. See, that's how we buy stuff.

Joey: Yeah, I'm an actor.

Rachel: Wow! Would I have seen you in anything?

Joey: I doubt it. Mostly regional work.

Monica: Oh wait, wait, unless you happened to catch the Reruns' production of Pinocchio ${ }^{16}$.

Chandler: 'Look, Gippetto, I'm a real live boy.'

Joey: I will not take this abuse. (Walks to the door and opens it to leave.)

Chandler: You're right, I'm sorry. (Burst into song and dances out of the door.) "Once I was a wooden boy, a little wooden boy..."

Monica: So how you doing today? Did you sleep okay? Talk to Barry? I can't stop smiling.

Rachel: I can see that. You look like you slept with a hanger in your mouth.
Monica: I know, he's just so, so.. Do you remember you and Tony DeMarco?

Rachel: Oh, yeah.

Monica: Well, it's like that. With feelings.

Rachel: Oh wow. Are you in trouble.

Monica: Okay. Okay. I am just going to get up, go to work and not think about him all day. Or else I'm just gonna get up and go to work. Rachel: Oh, look, wish me luck! Monica: What for?

Rachel: I'm gonna go get one of those (Thinks) job things.

(Monica exits.)

[Scene: Iridium, Monica is working as Frannie enters.]

Frannie: Hey, Monica!

Monica: Hey Frannie, welcome

back! How was Florida ${ }^{17}$ ?

Frannie: You had sex, didn't you?

Monica: How do you do that?

Monica: You know Paul?

Frannie: Paul the Wine Guy? Oh yeah, I know Paul.

Monica: You mean you know Paul like I know Paul?

Frannie: Are you kidding? I take credit for Paul. Y'know before me, there was no snap in his turtle for two years.

[Scene: Central Perk, everyone but Rachel is there.]

Joey: (sitting on the arm of the couch)Of course it was a line! Monica: Why?! Why? Why, why would anybody do something like that?

Ross: I assume we're looking for an answer more sophisticated than 'to get you into bed'.

Monica: Is it me? Is it like I have some sort of beacon that only dogs 
and men with severe emotional problems can hear?

Phoebe: All right, c'mere, gimme your feet. (She starts massaging them.)

Monica: I just thought he was nice, y'know?

Joey: (bursts out laughing again) I can't believe you didn't know it was a line!

(Monica pushes him off of the sofa as Rachel enters with a shopping bag.)

Rachel: Guess what?

Ross: You got a job?

Rachel: Are you kidding? I'm trained for nothing! I was laughed out of twelve interviews today.

Chandler: And yet you're surprisingly upbeat.

Rachel: You would be too if you found John and David boots ${ }^{18}$ on sale, fifty percent off!

Chandler: Oh, how well you know me...

Rachel: They're my new 'I don't need a job, I don't need my parents, I've got great boots' boots!

Monica: How'd you pay for them?

Rachel: Uh, credit card.

Monica: And who pays for that?

Rachel: Um... my... father.

[Scene: Monica and Rachel's, everyone is sitting around the kitchen table. Rachel's credit cards are spread out on the table along with a pair of scissors.]

Monica: C'mon, you can't live off your parents your whole life.

Rachel: I know that. That's why I was getting married.

Phoebe: Give her a break, it's hard being on your own for the first time.

Rachel: Thank you.

Phoebe: You're welcome. I remember when I first came to this city. I was fourteen. My mom had just killed herself and my step-dad was back in prison, and I got here, and I didn't know anybody. And I ended up living with this albino guy who was, like, cleaning windshields outside port authority, and then he killed himself, and then I found aromatherapy. So believe me, I know exactly how you feel.

(Pause)

Ross: The word you're looking for is 'Anyway'...

Monica: All right, you ready?

Rachel: I don't think so.

(Chandler slowly tries to hide the now dead plant from that morning when he and Joey poured their coffee into it.)

Ross: C'mon, cut. Cut, cut, cut,...

All: Cut, cut, cut, cut, cut, cut, cut... (She cuts one of them and they cheer.)

Monica: Welcome to the real world! It sucks. You're gonna love it! [Time Lapse, Rachel and Ross are watching a TV channel finishing its broadcast day by playing the national anthem.]

Monica: Well, that's it (To Ross) You gonna crash* on the couch?

Ross: No. No, I gotta* go home sometime.

Monica: You be okay?

Ross: Yeah.

Rachel: Hey Mon, look what I just found on the floor. (Monica smiles.) What?

Monica: That's Paul's watch. You just put it back where you found it. Oh boy. Alright. Goodnight, everybody.

Ross and Rachel: Goodnight.

(Monica stomps on Paul's watch and goes into her room.) 
Ross: Mmm. (They both reach for the last cookie) Oh, no-

Rachel: Sorry-

Ross: No no no, go-

Rachel: No, you have it, really, I don't want it-

Ross: Split it?

Rachel: Okay.

Ross: Okay. (They split it.) You know you probably didn't know this, but back in high school, I had a, um, major crush* on you.

Rachel: I knew.

Ross: You did! Oh.... I always figured* you just thought I was Monica's geeky ${ }^{\star}$ older brother.

Rachel: I did

Ross: Oh. Listen, do you think- and try not to let my intense vulnerability become any kind of a factor here- but do you think it would be okay if I asked you out? Sometime? Maybe?

Rachel: Yeah, maybe...

Ross: Okay... okay, maybe I will...

Rachel: Goodnight.

Ross: Goodnight.

(Rachel goes into her room and Monica enters the living room as Ross is leaving.)

Monica: See ya.... Wait wait, what's with you?

Ross: I just grabbed a spoon. (Ross exits and Monica has no idea what that means.)

[Scene: Central Perk, everyone is there.]

Joey: I can't believe what I'm hearing here.

Phoebe: (sings) I can't believe what I'm hearing here..

Monica: What? I-I said you had a-

Phoebe: (sings) What I said you had...

Monica: (to Phoebe) Would you stop?

Phoebe: Oh, was I doing it again?

All: Yes!
Rachel: (walks up with a pot of coffee) Would anybody like more coffee?

Chandler: Did you make it, or are you just serving it?

Rachel: I'm just serving it.

All: Yeah. Yeah, I'll have a cup of coffee.

Chandler: Kids, new dream... I'm in Las Vegas ${ }^{19}$. (Rachel sits down to hear Chandler's dream.) I'm Liza Minelli ${ }^{20}$ -

End 


\section{ANEXO II}

Nota: estos son los diálogos del DVD Temporada 1, Disco 1 Episodios 1-6, de Warner Bross Entertainment Inc. Distribuido en España por Warner Home Video Española. Existen otras versiones.

The One With the Sonogram at the End

Written by: Marta Kauffman \& David Crane

Transcribed by: guineapig

[Scene Central Perk, everyone's
there.]

Monica: What you guys don't understand is, for us, kissing is as important as any part of it.

Joey: Yeah, right!........'serious?

Phoebe: Oh, yeah!

Rachel: Everything you need to know is in that first kiss.

Monica: Absolutely.

Chandler: Yeah, I think for us, kissing is pretty much like an opening act, y'know? I mean it's like the stand-up comedian you have to sit through before Pink Floyd ${ }^{21}$ comes out.

Ross: Yeah, and-and it's not that we don't like the comedian, it's that-that... that's not why we bought the ticket.

Chandler: The problem is, though, after the concert's over, no matter how great the show was, you girls are always looking for the comedian again, y'know? I mean, we're in the car, we're fighting traffic... basically just trying to stay awake.

Rachel: Yeah, well, word of advice: Bring back the comedian. Otherwise next time you're gonna find yourself sitting at home, listening to that album alone.

Joey: (pause)....Are we still talking about sex?

[Scene: Museum of Prehistoric History, Ross and a co-worker (Marsha) are setting up an exhibit which includes some mannequins of cave people.]

Ross: No, it's good, it is good, it's just that- mm- doesn't she seem a little angry?

Marsha: Well, she has issues.

Ross: Does she.

Marsha: He's out banging other women over the head with a club, while she sits at home trying to get the mastodon smell out of the carpet!

Ross: Marsha, these are cave people. Okay? They have issues like 'Gee, that glacier's getting kinda close.' See?

Marsha: Speaking of issues, isn't that your ex-wife?

(Carol, Ross's ex-wife, has entered behind them and is standing outstide the exhibit.)

Ross: (trying to ignore her) No. No. Marsha: Yes, it is. Carol! Hi!

Ross: Okay, okay, yes, it is. (waves) How about I'll, uh, catch up with you in the lce Age.

(Marsha exits and Ross waves Carol into the exhibit.)

Ross: $\mathrm{Hi}$.

Carol: So.

Ross: You look great. I, uh... I hate that.

Carol: Sorry. You look good too. 
Ross: Ah, well, in here, anyone who... stands erect... So what's new? Still, uh...

Carol: A lesbian?

Ross: Well... you never know. How's, um.. how's the family?

Carol: Marty's still totally paranoid. Oh, and, uh-

Ross: Why- why are you here, Carol?

Carol: I'm pregnant.

Ross: Pregnant?!

[Scene: Monica and Rachel's, Chandler, Joey, Phoebe, and Monica are watching Three's Company. ]

Chandler: Oh, I think this is the episode of Three's Company ${ }^{22}$ where there's some kind of misunderstanding.

Phoebe:...Then I've already seen this one! (Turns off the TV.)

Monica: (taking a drink from Joey) Are you through with that?

Joey: Yeah, sorry, the swallowing slowed me down.

Monica: Whose little ball of paper is this?!

Chandler: Oh, uh, that would be mine. See, I wrote a note to myself, and then I realized I didn't need it, so I balled it up and... (sees that Monica is glaring at him) ...now I wish I was dead.

(Monica starts to fluff a pillow.)

Phoebe: She's already fluffed that pillow... Monica, you know, you've already fluffed that- (Monica glares at her.) -but, it's fine!

Monica: Look , I'm sorry, guys, I just don't wanna give them any more ammunition than they already have.

Chandler: Yes, and we all know how cruel a parent can be about the flatness of a child's pillow.

Phoebe: Monica- Hi! Um, Monica, you're scaring me. I mean, you're like, you're like all chaotic and twirly. And not-not in a good way.
Joey: Yeah, calm down. You don't see Ross getting all chaotic and twirly every time they come.

Monica: That's because as far as my parents are concerned, Ross can do no wrong. Y'see, he's the Prince. Apparently they had some big ceremony before I was born.

Chandler: (looking out the window)

Ew, ew, ew, ew ew ew ew ew!

Monica: What?

Chandler: Ugly Naked Guy got a Thighmaster ${ }^{23}$

All: Eeaagh!

(Rachel enters from her room.)

Rachel: Has anybody seen my

engagement ring?

Phoebe: Yeah, it's beautiful.

Rachel: Oh God, oh God, oh God oh God oh God oh God.... (Starts to look under the couch cushions.) Phoebe: No, look, don't touch that! Rachel: Oh, like I wasn't dreading tomorrow enough, having to give it back to him... 'Hi Barry! Remember me? I'm the girl in the veil who stomped on your heart in front of your entire family!' Oh God and now I'm gonna have to return the ring, without the ring, which makes it so much harder...

Monica: Easy Rach, we'll find it. (To all) Won't we! Chandler and Joey: Oh! Yeah! Joey: Alright, when'd'ya have it on last?

Phoebe: $D o y^{24}$ ! Probably right before she lost it!

Chandler: You don't get a lot of 'doy' these days...

Rachel: I know I had it this morning, and I know I had it when I was in the kitchen with...

Chandler: ...Dinah ${ }^{25}$ ?

Rachel: (looks at the lasagne and realizes something) Ohhhhh, don't be $\operatorname{mad} . .$. 
Monica: You didn't

Rachel: Oh, I am sorry...

Monica: I gave you one job! (Starts to examine the lasagne ${ }^{26}$ through the bottom of the glass pan.)

Rachel: Oh, but look how straight those noodles are!

Chandler: Now, Monica, you know that's not how you look for an engagement ring in a lasagne...

Monica: (puts down the lasagne) I just... can't do it.

Chandler: Boys? We're going in.

(Chandler, Joey, and Phoebe start to pick through the lasagne as there's a knock on the door which Monica answers.)

Ross: (standing outside the door).....Hi.

Monica: Wow. That is not a happy hi.

Ross: Carol's pregnant.

Phoebe: (while everyone else is stunned) Ooh! I found it

Monica: W-w-wh-... wha-... w-w-w-..

Ross: Yeah. Do that for another two hours, you might be where I am right about now. (He enters.)

Chandler: Kinda puts that whole pillow thing in perspective, huh, Mon?

Rachel: Well now, how-how do you fit into this whole thing?

Ross: Well, Carol says she and Susan want me to be involved, but if I'm not comfortable with it, I don't have to be involved.. basically it's entirely up to me.

Phoebe: She is so great! I miss her. Monica: What does she mean by 'involved'?

Chandler: I mean presumably, the biggest part of your job is done.

Ross: Anyway, they want me to go down to this- sonogram thing with them tomorrow.

Rachel: So what are you gonna do? Ross: I have no idea. No matter what I do, though, I'm still gonna be a father.
(Joey starts to eat the rest of the lasagne and everyone turns and stares at him.)

Joey: .....Well, this is still ruined, right?

[Scene, Monica and Rachel's, Monica and Ross are pouring wine for their parents.]

Mrs. Geller: Oh, Martha Ludwin's daughter is gonna call you. (Tastes a snack) Mmm! What's that curry taste?

Monica: Curry.

Mrs. Geller: Mmmm!

Ross: I- I think they're great! I, I really do.

Mr. Geller: (To Ross) Do you remember the Ludwins? The big one had a thing for you, didn't she? Mrs. Geller: They all had a thing for him.

Ross: Aw, Mom...

Monica: I'm sorry, why is this girl going to call me?

Mrs. Geller: Oh, she just graduated, and she wants to be something in cooking, or food, or.... I don't know. Anyway, I told her you had a restaurant-

Monica: No Mom, I don't have a restaurant, I work in a restaurant. Mrs. Geller: Well, they don't have to know that... (She starts to fluff the same pillow Monica fluffed multiple times earlier.)

Monica: Ross, could you come and help me with the spaghetti, please?

Ross: Yeah. (They go to the kitchen.)

Mrs. Geller: Oh, we're having spaghetti! That's.... easy.

Monica: I know this is going to sound unbelievably selfish, but, were you planning on bringing up the whole baby/lesbian thing? 
Because I think it might take some of the heat off me.

[Time Lapse, everyone is now eating.] Mrs. Geller: What that Rachel did to her life.... We ran into her parents at the $c l u b^{27}$, they were not playing very well.

Mr. Geller: I'm not gonna tell you what they spent on that wedding... but forty thousand dollars ${ }^{28}$ is a lot of money! Mrs. Geller: Well, at least she had the chance to leave a man at the altar.. Monica: What's that supposed to mean?

Mrs. Geller: Nothing! It's an expression.

Monica: No it's not.

Mr. Geller: Don't listen to your mother. You're independent, and you always have been! Even when you were a kid... and you were chubby, and you had no friends, you were just fine! And you would read alone in your room, and your puzzles...

[Time Lapse.]

Mr. Geller: Look, there are people like Ross who need to shoot for the stars, with his museum, and his papers getting published. Other people are satisfied with staying where they areI'm telling you, these are the people who never get cancer.

[Time Lapse.]

Mr. Geller: ...And I read about these women trying to have it all, and I thank God 'Our Little Harmonica' doesn't seem to have that problem.

Monica: (trying desperately to change the subject) So, Ross, what's going on with you? Any stories? (Digs her elbow into his hand.) No news, no little anecdotes to share with the folks? Ross: (pulls his hand away) Okay! Okay. (To his parents) Look, I, uh- I realize you guys have been wondering what exactly happened between Carol and me, and, so, well, here's the deal.
Carol's a lesbian. She's living with a woman named Susan. She's pregnant with my child, and she and Susan are going to raise the baby.

(Stunned silence ensues.)

Mrs. Geller: (To Monica) And you knew about this?!

Commercial Break

[Scene: Central Park, everyone's there.]

Joey: Your folks are really that bad, huh?

Ross: Well, y'know, these people are pros. They know what they're doing, they take their time, they get the job done.

Monica: Boy, I know they say you can't change your parents,... boy, if you could- (To Ross) -l'd want yours.

Ross: Must pee. (Goes to pee.)

Phoebe: Y'know, it's even worse when you're twins.

Rachel: You're twins?

Phoebe: Yeah. We don't speak. She's like this high-powered, driven career type.

Chandler: What does she do?

Phoebe: She's a waitress.

Rachel: All right, you guys, I kinda gotta clean up now. (They all start to leave.)

Monica: Chandler, you're an only child, right? You don't have any of this.

Chandler: Well, no, although I did have an imaginary friend, who... my parents actually preferred.

Rachel: The lights, please.. (Joey turns off the lights, and they all leave as Rachel starts to clean up. Ross enters from the bathroom.)

Ross: ... How long was I in there?

Rachel: I'm just cleaning up. 
Ross: D'ya.. uh.. d'ya need any help? Rachel: Uh.. okay, sure! Thanks! (She hands him the broom and sits down.) Ross: Anyway.. um.. (Starts to sweep.) So, you- uh- you nervous about Barry tomorrow?

Rachel: Oh.. a little..

Ross: Mm-hmm.

Rachel: A lot.

Ross: Mm.

Rachel: So, got any advice? Y'know, as someone who's recently beendumped?

Ross: Well, you may wanna steer clear of the word 'dumped'. Chances are he's gonna be this, this broken shell of a man, y'know, so you should try not to look too terrific, I know it'll be hard. Or, y'know, uh, hey!, I'll go down there, and I'll give Barry back his ring, and you can go with Carol and Susan to the OB/GYN...

Rachel: Oh, you've got Carol tomorrow.. When did it get so complicated?

Ross: Got me.

Rachel: Remember when we were in high school together?

Ross: Yeah.

Rachel: I mean, didn't you think you were just gonna meet somone, fall in love- and that'd be it? (Ross gazes at her.) ...Ross?

Ross: Yes, yes

Rachel: Oh! Man, I never thought I'd be here.. (She leans back onto his hand.)

Ross: Me either... (He pulls up a stool so that he doesn't have to move his hand.)

[Scene: Carol's OB/GYN, Carol is waiting.]

Ross: (entering) Sorry I'm late, I was stuck at work. There was this big dinosaur.. thing.. anyway.

(Susan enters holding a drink.) Susan: Hi.
Carol: Ross, you remember Susan. Ross: How could I forget?

Susan: Ross.

Ross: (they shake hands) Hello, Susan. (To Carol) Good shake. Good shake. So, uh, we're just waiting for...?

Carol: Dr. Oberman.

Ross: ..Dr. Oberman. Okay. And is he-

Susan: She.

Ross: -she, of course, she- uhfamiliar with our.. special situation? Carol: Yes, and she's very supportive.

Ross: Okay, that's great. (Susan gives her drink to Carol.) No, I'mOh.

Carol: Thanks.

Ross: (picks up a surgical instrument and mimes a duck with it) Quack, quack.

Carol: Ross? That opens my cervix. (He drops it in horror.)

[Scene Barry's office, Barry is working on patient, Robbie, as Rachel enters.]

Rachel: Barry?

Barry: C'mon in.

Rachel: (hesitates) Are you sure?

Barry: Yeah! It's fine, it's fine. Robbie's gonna be here for hours.

Robbie: Huh?!

Barry: So, how ya doin?

Rachel: I'm- uh- I'm okay... You look great!

Barry: Yeah, well..

Bernice: (over intercom) Dr. Farber, Jason Greenstein's gagging.

Barry: (answering the intercom) Be right there. (To Robbie and Rachel) Be back in a sec.

(As Barry exits Robbie stares at Rachel.)

Rachel: I dumped him.

Robbie: Okay. 
[Scene: Carol's OB/GYN, they're talking about how this is going to work.]

Ross: So, um- so how's this, uh, how's this gonna work? Y'know, with us? Y'know, when, like, important decisions have to be made?

Carol: Give me a 'for instance'.

Ross: Well, uh, uh, I don't know, okay, okay, how about with the, uh, with the baby's name?

Carol: Marlon-

Ross: Marlon?!

Carol: -if it's a boy, Minnie if it's a girl.

Ross: ...As in Mouse ${ }^{29}$ ?

Carol: As in my grandmother.

Ross: Still, you- you say Minnie, you hear Mouse. Um, how about, um.. how about Julia?

Carol: Julia..

Susan: We agreed on Minnie.

Ross: 'S'funny, um, uh, we agreed we'd spend the rest of our lives together. Things change, roll with the punches. I believe Julia's on the table..?

[Scene: Barry's office, Rachel is doing her makeup in the mirror on Barry's lamp as Barry enters.]

Barry: Sorry about that. So. What have you been up to?

Rachel: Oh, not much. I-I got a job.

Barry: Oh, that's great.

Rachel: Why are- why are you so tanned?

Barry: Oh, I, uh- I went to Aruba.

Rachel: Oh no. You went on our honeymoon alone?

Barry: No. I went with, uh.. Now, this may hurt.

Robbie: Me?!

Barry: No! (To Rachel) I went with Mindy.

Rachel: Mindy?! My maid of honor, Mindy?!

Barry: Yeah, well, uh, we're kind of a thing now.
Rachel: Oh! Well, um.. (Grabs his forehand) You've got plugs!

Barry: Careful! They haven't quite taken yet.

Rachel: And you've got lenses! But you hate sticking your finger in your eye!

Barry: Not for her. Listen, I really wanted to thank you.

Rachel: Okay.

Barry: See, about a month ago, I wanted to hurt you. More than I've ever wanted to hurt anyone in my life. And I'm an orthodontist.

Rachel: Wow.

Barry: You know, you were right? I mean, I thought we were happy. We weren't happy. But with Mindy, now I'm happy. Spit.

Rachel: What?

Robbie: Me. (Spits.)

Rachel: Anyway, um, (Gets the ring out of her purse.) I guess this belongs to you. And thank you for giving it to me.

Barry: Well, thank you for giving it back.

(Barry and Rachel look at each other.)

Robbie: Hello?!

[Scene: Carol's OB/GYN, they're still arguing about what to name the baby.]

Susan: Oh, please! What's wrong with Helen?

Ross: Helen Geller? I don't think so.

Carol: Hello? It's not gonna be Helen Geller.

Ross: Thank you!

Carol: No, I mean it's not Geller.

Ross: What, it's gonna be Helen Willick?

Carol: No, actually, um, we talked about Helen Willick-Bunch.

Ross: Well, wait a minute, whawhy is she in the title? 
Susan: It's my baby too.

Ross: Oh, 's'funny, really? Um, I don't remember you making any sperm.

Susan: Yeah, and we all know what a challenge that is!

Carol: All right, you two, stop it!

Ross: No no no, she gets a credit, hey, I'm in there too.

Carol: Ross. You're not actually suggesting Helen Willick-BunchGeller? 'Cause I think that borders on child abuse.

Ross: Of course not, I'm... suggesting Geller-Willick-Bunch.

Susan: Oh, no, nonononono, you see what he's doing? He knows no-one's gonna say all those names, so they'll wind up calling her Geller, then he gets his way!

Ross: My way?! You-you think this is my way? Believe me, of all the ways I ever imagined this moment in my life being, this is not my way- y'know what? Uh, um, this is too hard. I'm not, I can't do-

Dr. Oberman: (entering) Knock knock!How are we today? Any nausea?

All: Yeah. Yeah. A little.

Dr. Oberman: Well, I was just wondering about the mother-to-be, but.. thanks for sharing. (To Carol) Uh, lie back..

Ross: You- uh- y'know what, I'm gonna go. I don't- I don't think I can be involved in this particular thing right now.

(He turns to go, but the sound of the sonogram catches his ear. He returns and stares at it.)

Ross: Oh my God.

Susan: Look at that.

Carol: I know.

Closing Credits

[Scene: Monica and Rachel's apartment, everyone is watching the tape of the sonogram. Rachel is on the phone.]

Ross: Well? Isn't that amazing?

Joey: What are we supposed to be seeing here?

Chandler: I dunno, but.. I think it's about to attack the Enterprise ${ }^{30}$.

Phoebe: You know, if you tilt your head to the left, and relax your eyes, it kinda looks like an old potato.

Ross: Then don't do that, alright? Phoebe: Okay!

Ross: (walks over to where Monica is standing)Monica. Whaddya think?

Monica: (welling up) Mm-hmm.

Ross: Wh- are you welling up?

Monica: No.

Ross: You are, you're welling up.

Monica: Am not!

Ross: You're gonna be an aunt.

Monica: (pushes him and starts to cry) Oh shut up!

Rachel: (on phone) $\mathrm{Hi}$, Mindy. $\mathrm{Hi}$, it-it's Rachel. Yeah, I'm fine. I-I saw Barry today. Oh, yeah, yeah he-he told me. No, no, it's okay. I hope you two are very happy, I really do. Oh, oh, and Mind, y'know, if-if everything works out, and you guys end up getting married and having kids- and everything- I just hope they have his old hairline and your old nose. (Slams the phone down.) (To everyone) Okay, I know it was a cheap shot, but I feel so much better now.

End 
Hikma 9 (2010), 161-195 